\title{
Angiotensin II-induced aortic ring constriction is mediated by phosphatidylinositol 3-kinase/L-type calcium channel signaling pathway
}

\author{
Kee Hun Do ${ }^{1,2}$, Min Sung Kim ${ }^{1,2}$, \\ Jae Ho Kim ${ }^{1,3}$, Byung-Yong Rhim ${ }^{2}$, \\ Won Suk Lee ${ }^{1,2}$, Chi Dae Kim ${ }^{1,2}$ \\ and Sun Sik Bae $e^{1,2,4}$ \\ ${ }^{1} \mathrm{MRC}$ for Ischemic Tissue Regeneration and Medical Research Institute \\ ${ }^{2}$ Department of Pharmacology \\ ${ }^{3}$ Department of Physiology \\ Pusan National University School of Medicine \\ Yangsan 626-870, Korea \\ ${ }^{4}$ Corresponding author: Tel, 82-51-510-8065; \\ Fax, 82-51-510-8068; E-mail, sunsik@ pusan.ac.kr \\ DOI 10.3858/emm.2009.41.8.062
}

Accepted 19 March 2009

Abbreviations: Akt/PKB, Akt/protein kinase B; Angll, angiotensin II; PI3K, phosphatidylinositol 3-kinase; $\mathrm{PIP}_{3}$, phosphatidylinositol 3,4,5-trisphosphate; RASMC, rat aortic smooth muscle cell; VSMC, vascular smooth muscle cell

\begin{abstract}
Angiotensin II (Angll) is a crucial hormone that affects vasoconstriction and exerts hypertrophic effects on vascular smooth muscle cells. Here, we showed that phosphatidylinositol 3-kinase-dependent calcium mobilization plays pivotal roles in Angll-induced vascular constriction. Stimulation of rat aortic vascular smooth muscle cell (RASMC)-embedded collagen gel with Angll rapidly induced contraction. Angll-induced collagen gel contraction was blocked by pretreatment with a phosphatidylinositol 3-kinase (PI3K) inhibitor (LY294002) whereas ERK inhibitor (PD98059) was not effective. Angll-induced collagen gel contraction was significantly blocked by extracellular calcium depletion by EGTA or by nifedipine which is an L-type calcium channel blocker. In addition, Angll-induced calcium mobilization was also blocked by nifedipine and EGTA, whereas intracellular calcium store-depletion by thapsigargin was not effective. Finally, pretreatment of rat aortic ring with LY294002 and nifedipine significantly reduced Angll-induced constriction. Given these results, we suggest that PI3K-dependent activation of L-type calcium channels might be involved in
\end{abstract}

Angll-induced vascular constriction.

Keywords: calcium; calcium channels, L-type; muscle contraction; muscle, smooth; 1-phosphatidylinositol 3-kinase

\section{Introduction}

The renin-angiotensin system (RAS) plays crucial roles in many physiological processes. Angiotensin II (Angll) is formed from a series of proteolytic cleavages of angiotensinogen to angiotensin I (Angl) by renin, and subsequent cleavage of Angl to Angll by angiotensin converting enzyme (ACE). Acute roles for Angll have been implicated in the regulation of plasma volume control, vasoconstriction, and blood pressure control, whereas chronic stimulation with Angll induces hyperplasia and hypertrophy of vascular smooth muscle cells (VSMCs) (Geisterfer et al., 1988).

Among its pleiotropic effects, vasoconstrictioninduced blood pressure control is the major function of Angll. The receptors for Angll include angiotensin type 1 receptor $\left(A T_{1} R\right)$ and angiotensin type 2 receptor $\left(A T_{2} R\right)$, which belong to the seven trans-membrane superfamily that is coupled with $G$ proteins. Occupation of $A T_{1} R$ by Angll results in intracellular calcium mobilization, which binds to calmodulin and activates myosin light chain kinase (MLCK). Activated MLCK eventually leads to the phosphorylation of the myosin light chain which causes it to interact with actin, causing contraction of VSMCs (Yan et al., 2003). MLCK is negatively regulated by myosin light chain phosphatase (MLCP), which is inactivated by Rho kinase. Activation of the Rho kinase signaling pathway leads to sustained contraction of VSMCs (Uehata et al., 1997). Therefore, intracellular calcium mobilization is a key mediator of VSMC contraction.

Binding of Angll to $A T_{1} R$ has been reported to activate several $G$ proteins including $G_{\alpha_{q} / 11}, G_{\alpha_{12 / 13}}$, and $G_{\beta \gamma}$ complexes. Activation of $G$ proteins leads to the activation of downstream signaling mole-

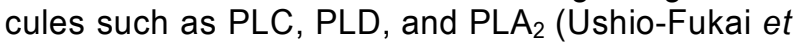
al., 1999a). Among the PLC isoforms, PLC- $\beta$ isoform is coupled with $G$ proteins and generates inositol tris-phosphate $\left(\mathrm{IP}_{3}\right)$ from phosphatidylinositol 4,5- 
bisphosphate $\left(\mathrm{PIP}_{2}\right)$ by hydrolytic cleavage (Rhee, 2001). IP 3 evokes calcium mobilization by stimulating $\mathrm{IP}_{3}$ receptors on intracellular calcium storage sites such as the endoplasmic reticulum. Elevation of intracellular calcium concentrations eventually leads to VSMC contraction. In addition to the effect of Angll on calcium mobilization, Angll also causes membrane $\mathrm{NAD}(\mathrm{P}) \mathrm{H}$ oxidase to generate reactive oxygen species (ROS) such as superoxide and hydrogen peroxide $\left(\mathrm{H}_{2} \mathrm{O}_{2}\right)$. For instance, Angll causes NAD(P)H oxidase subunits Nox1 and Nox4 to generate ROS (Lassegue et al., 2001), although the molecular mechanism is still not clear. Angll-dependent production of ROS affects the activation of many signaling molecules including p38 MPAK, Akt, and ERK1/2 (Ushio-Fukai et al., 1999b; Nishida et al., 2005). Although p38 MAPK and ERK $1 / 2$ are activated by Angll stimulation, these kinases are implicated in VSMC differentiation, proliferation and migration (Sugden and Clerk 1997; Taniyama et al., 2004).

Angll also cross-communicates with several tyrosine kinases, including receptor tyrosine kinases such as EGF-R, PDGF-R, insulin receptor (IR), and nonreceptor tyrosine kinases such as the c-Src family kinases, calcium-dependent proline-rich kinase 2 (Pyk2), focal adhesion kinase (FAK) and Janus kinase (JAK). The major function of Angll-dependent activation of nonreceptor tyrosine kinases seems to be the regulation of focal adhesion complex formation and actin bundling
(Taniyama et al., 2003). Angll can trans-activate receptor tyrosine kinases independent of growth factors. For instance, stimulation of VSMC with Angll stimulates formation of Shc and Grb2 complex with PDGF-R (Linseman et al., 1995). Once activated, receptor tyrosine kinases evoke the phosphatidylinositol 3-kinase (PI3K)/3-phosphoinositide-dependent kinase-1 (PDK-1)/Akt cascade, which leads to growth, metabolism, survival, and remodeling of VSMCs.

The major physiological function of Angll is VSMC contraction and maintaining vascular tone through the regulation of calcium mobilization. Although PLC- $\beta$-dependent intracellular calcium mobilization during Angll stimulation is important for VSMC contractions, recent evidence also supports the idea that Angll increases myocardial activity through the augmentation of inward calcium currents through L-type calcium channels (Baker et al., 1992). Other evidence has supported the argument that $\mathrm{G}_{\beta \gamma}$ directly activates $\mathrm{PI} 3 \mathrm{~K} \gamma$ isoform to generate $\mathrm{PIP}_{3}$ (Viard et al., 1999), which eventually stimulates L-type calcium channels in vascular myocytes from portal vein (Le Blanc et al., 2004). However, there is no direct evidence that PI3K-dependent calcium mobilization is important for vascular constriction upon Angll stimulation. Here we provide strong evidence that Angll-dependent rat aortic ring constriction is mediated by PI3K-mediated L-type calcium channel activation.
A

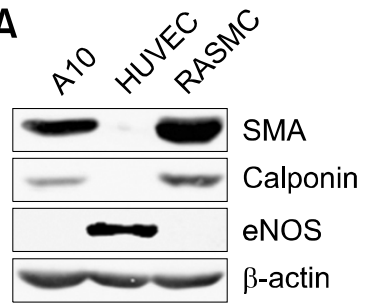

B

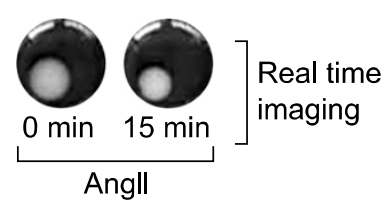

C

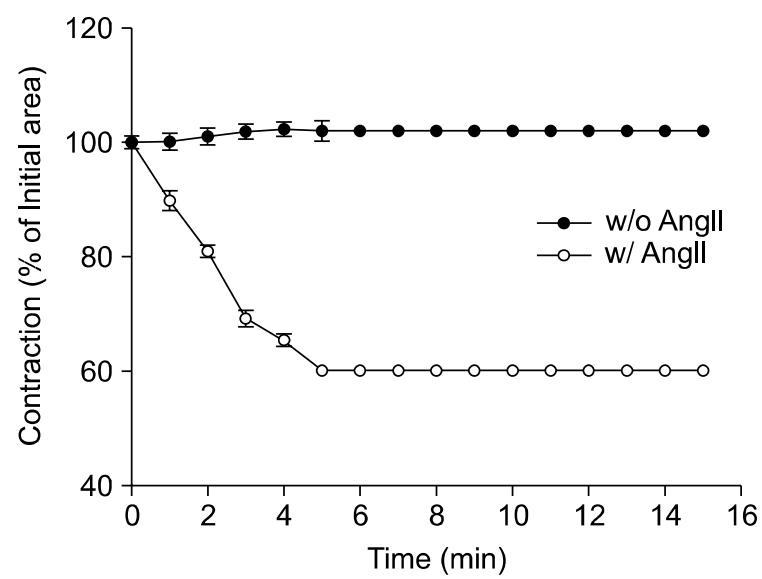

Figure 1. Angll-induced RASMC contraction. (A) Cells from rat aortic smooth muscle were subjected to western blot analysis using the indicated antibodies. A10 and HUVEC cell lysates were included as markers for smooth muscle and endothelial cells, respectively. (B) Isolated RASMCs were embedded in collagen gel matrix as described in Methods. Gel contraction was initiated by addition of Angll $(1 \mu \mathrm{M})$, and images were captured as described in Methods. Images are representative of two independent experiments each done in triplicate. (C) RASMC-embedded collagen gel was stimulated with either vehicle or Angll $(1 \mu \mathrm{M})$, images were taken, and the surface area of the collagen gel was analyzed as described in Methods. Data are mean \pm S.D. of two independent experiments ( $n=3$ for each experiment). 


\section{Results}

\section{Angll-induced contraction of isolated RASMCs}

Previously, it was reported that Angll regulates calcium mobilization through PI3K- $\beta$-dependent L-type calcium channel activation in vascular myocytes from portal vein (Viard et al., 1999). To understand the role of PI3K-dependent L-type calcium channel modulation in VSMCs from thoracic aorta, we isolated rat aortic smooth muscle cells (RASMCs). As shown in Figure 1A, isolated RASMC expressed vascular smooth muscle cell marker proteins such as smooth muscle actin (SMA) and calponin. On the other hand, RASMCs did not express endothelial nitric oxide synthase (eNOS) which is an endothelial cell marker protein. A10 and human umbilical vein endothelial cell (HUVEC) extracts were used as positive controls of smooth muscle and endothelial cells, respectively. Isolated RASMCs rapidly contracted within $5 \mathrm{~min}$ after exposure to $1 \mu \mathrm{M}$ of Angll (Figure 1B and $1 \mathrm{C}$ ). However, Angll did not induce the contraction of A10 and HUVEC cells (data not shown).

\section{PI3K- and L-type calcium channel-dependent RASMC contraction}

Since PI3K is involved in the Angll-induced calcium mobilization of smooth muscle cells from portal vein (Viard et al., 1999), we next examined the possible role of $\mathrm{PI3K}$ in VSMC contractions. As shown in Figure $2 \mathrm{~A}$, pretreatment with the $\mathrm{PI} 3 \mathrm{~K}$ inhibitor, LY294002 (10 $\mu$ M), significantly reduced Angll-induced RASMC contractions. However, inhibition of the ERK1/2 signaling pathway by PD98059 $(10 \mu \mathrm{M})$ slightly potentiated Angll-induced RASMC contractions. Inhibition of PLC by U73122 $(10 \mu \mathrm{M})$ also blocked Angll-induced RASMC contraction (data not shown). Since calcium mobilization is important for smooth muscle cell contraction, we examined the effect of calcium channel blocker on Angll-induced RASMC contractions. As shown in Figure 2B, chelation of extracellular calcium by EGTA ( $5 \mathrm{mM}$ ) or blocking L-type calcium channels by nifedipine $(20 \mu \mathrm{M})$ strongly inhibited Angll-induced RASMC contraction. However, depletion of intracellular calcium by thapsigargin $(1 \mu \mathrm{M})$ did not affect Angll-induced RASMC contraction.

\section{Inhibition of calcium mobilization by PI3K and L-type calcium channel inhibitors}

Since PI3K and L-type calcium channel inhibitors strongly blocked Angll-induced RASMC contraction, we examined the effect of these inhibitors on intracellular calcium mobilization. As shown in Figure 3A, pretreatment of RASMC with LY294002 completely blocked Angll-induced calcium mobilization, whereas pretreatment of PD98059 did not affect Angll-induced calcium mobilization. Angll-induced calcium mobilization was also completely blocked by extracellular calcium chelation (Figure 3B). Inhibition of L-type calcium channels by nifedipine significantly attenuated Angll-induced calcium mobilization.
A

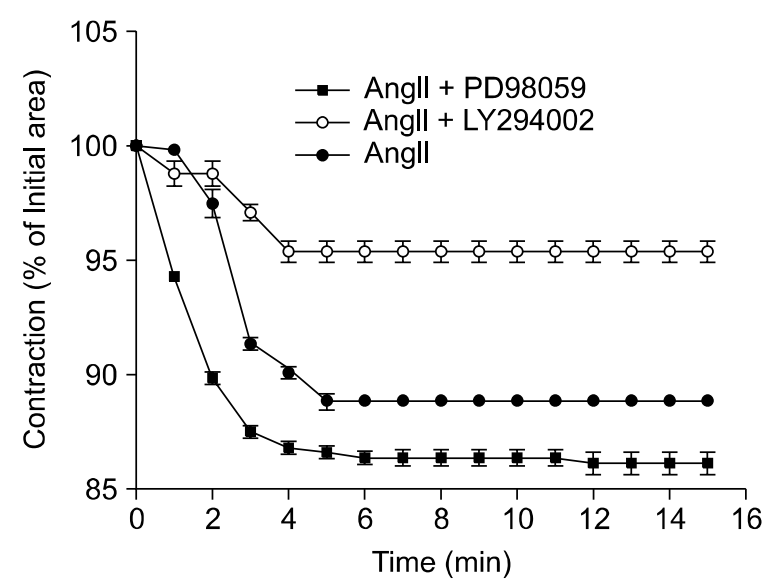

B

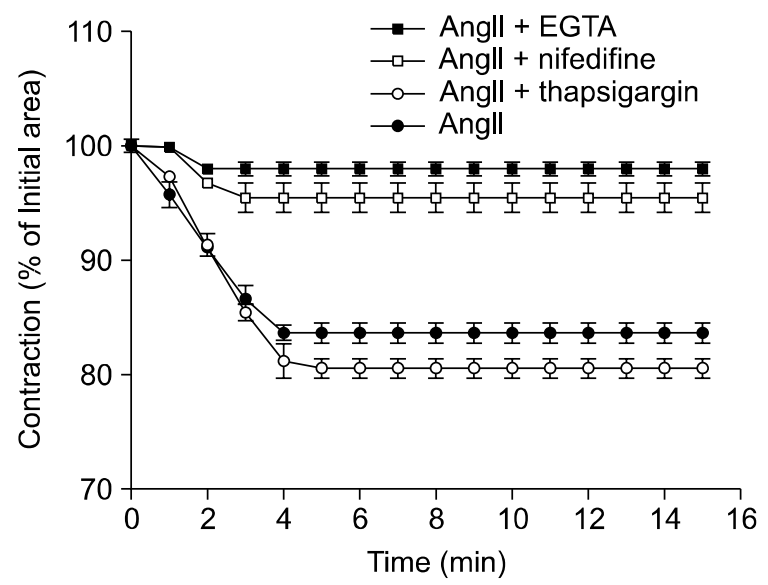

Figure 2. PI3K and L-type calcium channels are important for RASMC contraction in vitro. (A) RASMCs-embedded in collagen gel matrix were pretreated with vehicle, LY294002 $(10 \mu \mathrm{M})$, or PD98059 $(10 \mu \mathrm{M})$ for $20 \mathrm{~min}$, and then stimulated with Angll $(1 \mu \mathrm{M})$. Data are mean \pm S.D. of two independent experiments ( $n=3$ for each experiment). (B) RASMCs-embedded in collagen gel matrix were pretreated with vehicle, EGTA $(5 \mathrm{mM})$, thapsigargin $(1 \mu \mathrm{M})$, or nifedipine $(20 \mu \mathrm{M})$ for $20 \mathrm{~min}$, and then stimulated with Angll $(1 \mu \mathrm{M})$. Data are mean \pm S.D. of two independent experiments $(n=3$ for each experiment). 
A

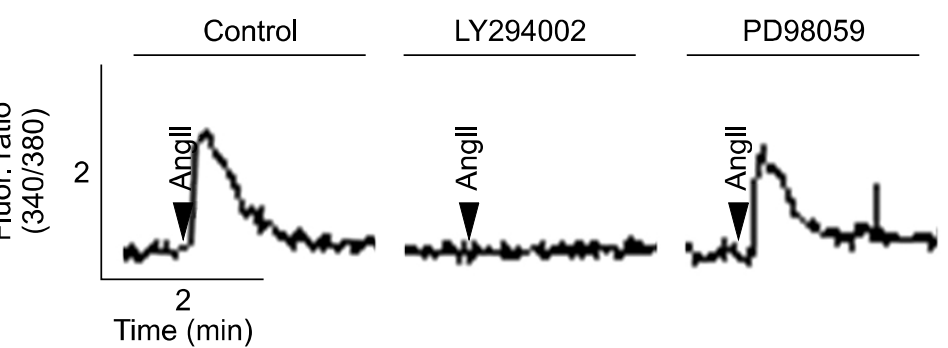

B

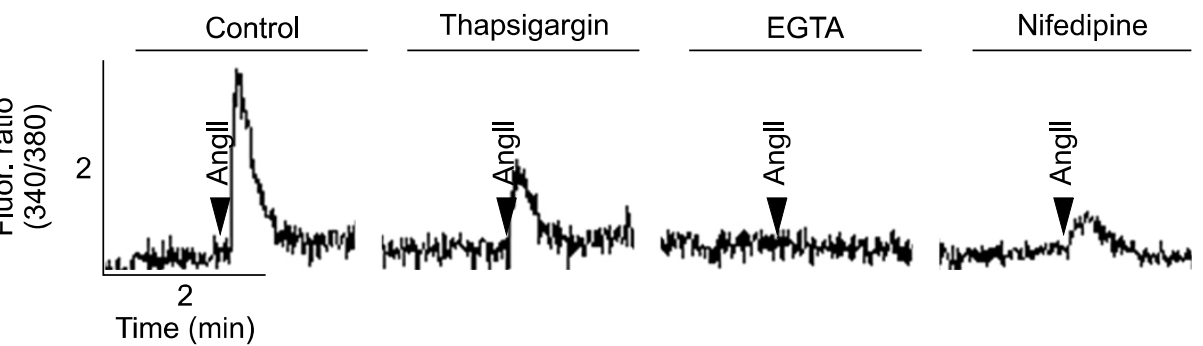

Figure 3. Angll induces calcium mobilization through PI3K- in an L-type calcium channel-dependent manner. (A) RAMSCs were pretreated with vehicle, LY294002 $(10 \mu \mathrm{M})$, or PD98059 $(10 \mu \mathrm{M})$ for $20 \mathrm{~min}$, followed by stimulation with Angll (1 $\mu \mathrm{M})$. Images are representative of three independent experiments. The time of Angll stimulation is indicated by an arrow head. (B) RASMCs were pretreated with vehicle, thapsigargin $(1 \mu \mathrm{M})$, EGTA $(5 \mathrm{mM})$, or nifedipine $(20 \mu \mathrm{M})$ for $20 \mathrm{~min}$, followed by stimulation with Angll (1 $\mu \mathrm{M})$. Images are representative of three independent experiments. The time of Angll stimulation is indicated by an arrow head.

\section{PI3K- and L-type calcium channel-dependent constriction of rat aorta}

Since calcium mobilization and contraction of RASMC were mediated by PI3K and L-type calcium channels, we extended the experiments to ex vivo conditions to clarify the effect of PI3K and L-type calcium channels on vascular constriction. As shown in Figure 4A, stimulation of thoracic aorta with Angll resulted in about $30-35 \%$ contraction of vessels. Angll-induced vascular contraction was significantly blocked by a PI3K inhibitor, LY294004, whereas inhibition of ERK1/2 signaling pathway did not affect Angll-induced vascular

A

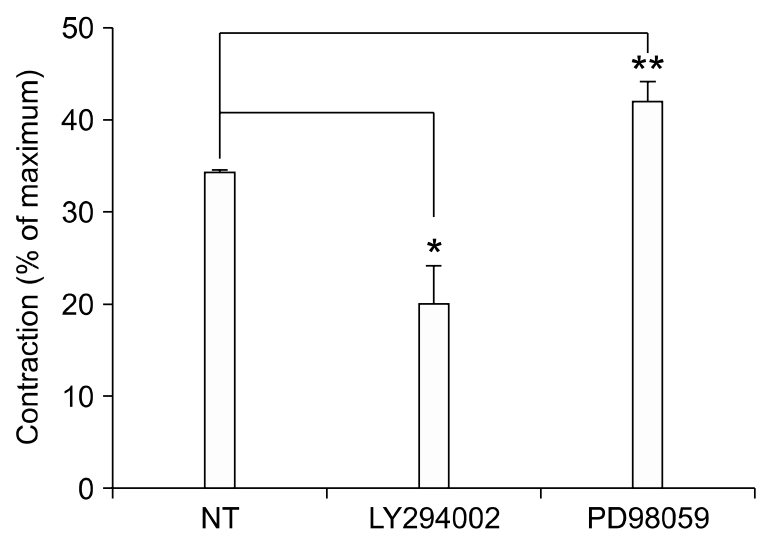

contractions. Depletion of extracellular calcium by EGTA strongly inhibited Angll-induced vascular contraction (Figure 4B). In addition, blocking of L-type calcium channels by nifedipine significantly inhibited Angll-induced vascular contractions. In contrast, depletion of intracellular calcium stores by thapsigargin did not affect Angll-induced vascular contraction.

\section{Discussion}

A plethora of evidence suggests that Angll plays

B

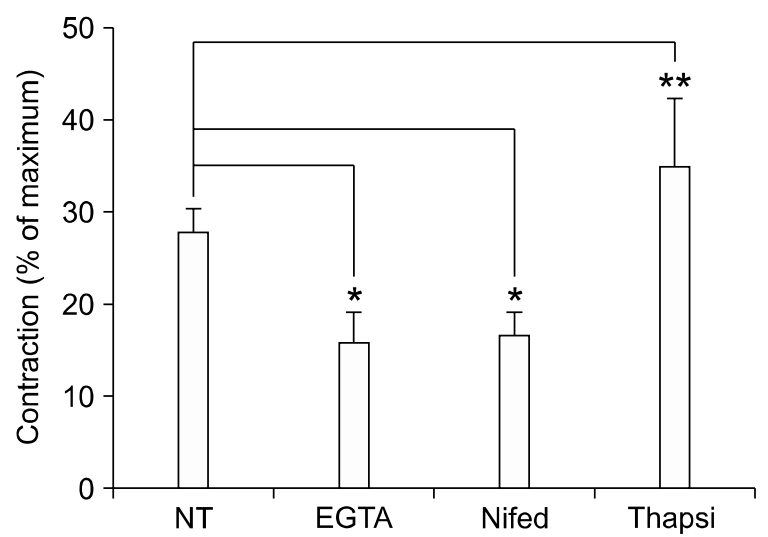

Figure 4. PI3K and L-type calcium channels regulate Angll-induced contractions of thoracic aorta. (A) Thoracic aortic rings were isolated from rats and pretreated with vehicle alone, LY294002 $(10 \mu \mathrm{M})$, or PD98059 $(10 \mu \mathrm{M})$ for $20 \mathrm{~min}$, and then stimulated with Angll $(1 \mu \mathrm{M})$. Contraction is expressed as a percent of $\mathrm{KCl}(60 \mathrm{mM})$-induced maximum tension. Data are mean \pm S.D. of two independent experiments $(n=2$ for each experiment). *Significantly different from vehicle-pretreated aortic rings $(P<0.05)$. ${ }^{* *}$ Values were not statistically different from vehicle-pretreated aortic rings $(P>0.05)$. (B) The Angll $(1 \mu \mathrm{M})$-induced tension of thoracic aortic rings was measured after pretreatment with vehicle, EGTA $(5 \mathrm{mM})$, nifedipine $(20 \mu \mathrm{M})$, or thapsigargin $(1$ $\mu \mathrm{M})$ for $20 \mathrm{~min}$. 
key roles in the regulation of blood pressure. Angll acutely increases blood pressure by induction of blood vessel constriction. In fact, antagonists of $A T_{1} R$ effectively reduced blood pressure in hypertensive rats (Dendorfer et al., 2005). It has been reported that Angll activates many signaling pathways including the PLC, Ras/MEKK/MAPK, and p38 MAPK pathways (Smith et al., 1984; Meloche et al., 2000; Ishihata et al., 2002). In addition, Angll stimulates PI3K through the modulation of $\mathrm{G}_{\beta \gamma}$ (Viard et al., 1999). Likewise, pharmacological inhibition of PI3K resulted in the attenuation of RASMC contraction as well as in calcium mobilization (Figure 2-4). However, MAPK signaling pathway seems not to be involved in Angll-dependent physiological responses. Currently, the involvement of MAPK signaling pathways in VSMC contractions is controversial. Nevertheless, our results clearly showed that pharmacological inhibition of MAPK signaling pathway did not affect VSMC contraction both in vitro and ex vivo (Figure $2 A$ and $4 A$ ). More importantly, inhibition of MAPK signaling pathway did not alter Angll-induced calcium mobilization (Figure $3 \mathrm{~A}$ ), which is a very important signaling response during Angll-induced vascular smooth muscle contraction. Therefore, the MAPK signaling pathway seems to be involved in prolonged responses such as proliferation and differentiation (Marrero et al., 1997; Yamada et al., 1999) rather than in acute responses.

Angll-induced calcium mobilization is a crucial event during VSMC contraction. Apparently, Angll stimulates PLC isoforms to generate $\mathrm{IP}_{3}$ through the activation of $\mathrm{G}_{\alpha_{\mathrm{q} / 11}}, \mathrm{G}_{12 / 13}$, and $\mathrm{G}_{\beta \gamma}$. Calcium is released from endoplasmic reticulum via $\mathrm{IP}_{3^{-}}$ operated calcium channels. Hence, PLC-mediated calcium mobilization has been implicated in the regulation of VSMC contraction. The possible involvement of PLC was suggested by experiments in which electroporation of anti- $G \alpha_{q / 11}$ antibody to VSMC suppressed Angll-induced $\mathrm{IP}_{3}$ production (Ushio-Fukai et al., 1998). However, there is no direct link between $\mathrm{IP}_{3}$-operated calcium mobilization and VSMC contraction. In contrast, our data showed that depletion of intracellular calcium stores by thapsigargine inhibited $50 \%$ of Angll-induced calcium mobilization (Figure 3B). This result indicates that Angll partially stimulates $\mathrm{IP}_{3}$-operated calcium mobilization. However, blocking $\mathrm{IP}_{3}$-operated calcium mobilization was not enough to block Angll-induced VSMC contractions both in vitro and ex vivo (Figure $2 \mathrm{~B}$ and $4 \mathrm{~B}$ ). These results suggest that another mechanism of calcium mobilization is important for VSMC contractions. Currently, the involvement of PLC-mediated signaling pathways in VSMC contractions is still ambiguous. Studies using a genetically modified mouse model of PLC will provide detailed molecular mechanism of PLC-dependent VSMC contraction.

Although Angll-induced PLC activation and subsequent calcium mobilization have been implicated as major signaling pathways, it has been reported that Angll also induces the activation of growth factor receptor signaling pathways. For instance, stimulation of VSMC with Angll activates the tyrosine kinase signaling pathway including MAPK (Watts et al., 1998). However, pharmacological inhibition of MAPK does not affect VSMC contraction. Likewise, our results showed that pharmacological inhibition of the MAPK signaling pathway affected neither Angll-induced VSMC contraction nor calcium mobilization (Figure $2 \mathrm{~A}, 3 \mathrm{~A}$ and $4 \mathrm{~A}$ ). The involvement of other signaling pathways rather than G protein-coupled PLC activation has been implicated by recent studies. The atypical PI3K class is directly activated by the $G_{\beta \gamma}$ subunits of $G$ proteins (Viard et al., 1999). Consistent with this, our results showed that pharmacological inhibition of PI3K strongly attenuated Angll-induced calcium mobilization and VSMC contraction (Figure $3 \mathrm{~A}$ and 4A). PI3K-dependent activation of calcium mobilization was further demonstrated by Le Blanc et al. (2004). They showed that PIP3, which is a product of PI3K, can directly activate L-type calcium channels. It is also supported by our results that depletion of extracellular calcium or blocking of L-type calcium channels significantly blocks Angllinduced calcium mobilization (Figure 3B). In addition, the link between L-type calcium channel opening and VSMC contraction was further confirmed by showing that inhibition of L-type calcium channels blunted Angll-induced VSMC contraction both in vitro and ex vivo (Figure 2B and $4 \mathrm{~B}$ ). Therefore, it is quite clear that direct activation of L-type calcium channels by $\mathrm{PIP}_{3}$ is important for the regulation of VSMC contraction. The downstream effector molecule of $\mathrm{PIP}_{3}$ seems not to be involved in Angll-dependent VSMC contractions since pharmacological inhibition of Akt/PKB by SH-5 (10 $\mu \mathrm{M})$ did not affect Angll-induced VSMC contraction (data not shown).

Because inhibition of PLC activity by $\mathrm{U} 73122$ also suppressed Angll-induced VSMC contraction (data not shown) we cannot exclude possible involvement of PLC activation in Angll-dependent VSMC contraction. Consistent with this, depletion of intracellular calcium stores by thapsigargin resulted in a $50 \%$ reduction of Angll-induced calcium mobilization (Figure 3B), demonstrating PLC-mediated calcium mobilization in Angll-stimulated VSMCs. Nonetheless, pretreatment of thapsigargin barely affected Angll-induced VSMC contractions 
(Figure 4B). These results could be interpreted as follows. First, it is possible that depletion of intracellular calcium stores is not sufficient for the dropping effective concentration of calcium to evoke VSMC contraction. Second, in addition to calcium mobilization, another signaling pathway can be diverted from PLC, and lead the VSMC contraction. Consistent with this idea, it has been reported that PKC also regulates Angll-induced VSMC contractions (Yu et al., 2004). Therefore, multiple signaling pathways seem to be involved in the regulation of Angll-induced VSMC contractions.

In summary, we have demonstrated that Angllinduced aortic ring constriction is mediated by PI3K-dependent regulation of L-type calcium channel activity. Our studies suggest that changes in intracellular calcium concentration by L-type calcium channels are important for arterial smooth muscle contraction, which is important for in vivo responses in Angll-dependent acute blood pressure regulation. The analysis of calcium modulation using knock-out animal models will shed more light on the Angll-mediated signaling pathway of VSMC contraction.

\section{Methods}

\section{Reagents}

All cell culture media and supplements were purchased from Cambrex Corp. Anti-SMA and anti-calponin antibodies were purchased from Sigma-Aldrich. Anti- $\beta$-actin antibody was obtained from MP Biomedicals. Anti-eNOS antibody was from BD Transduction Laboratories. Collagen gel was purchased from BD Bioscience and Fura-2-AM was from Invitrogen. LY294002 and PD98059 were obtained from Calbiochem. Nifedipine, thapsigargin, collagen, gelatin, and Angll were purchased from Sigma-Aldrich. All other high quality reagents were purchased from Sigma-Aldrich unless otherwise indicated.

\section{Rat aortic smooth muscle cell (RASMC) preparation}

Pathogen-free Sprague-Dawley rats (6 to 8 weeks old) were housed under diurnal lighting conditions and allowed unlimited access to feed and tap water. All animal experiments were performed under university animal welfare guidelines. Aortic smooth muscle cells were isolated from the thoracic aorta by a tissue explanting method as described previously (Hall et al., 1991). Briefly, sodium barbital anesthetized rats were perfused with PBS for 5 $\mathrm{min}$. Thoracic aorta was aseptically isolated and surrounding fat and connective tissues were discarded. Vessels were longitudinally cut and the lumen side was scraped with a razor blade to remove the intima. Vessels were fragmented into 3-5 mm lengths and explanted lumen side down on collagen-coated culture dishes. Tissue fragments were maintained in DMEM $/ 10 \%$ FBS with changing of the medium every two days. After seven days of explanting, tissue fragments were discarded and sprouted VSMCs were collected and used for experiments.

\section{Collagen gel contraction assay}

To measure RASMC contractility, RASMCs from confluent cultures were trypsinized, resuspended in serum free DMEM and diluted to $1 \times 10^{6} \mathrm{cells} / \mathrm{ml}$. The cell suspension was mixed on ice with collagen gel solution $(6 \mathrm{mg} / \mathrm{ml}$ of collagen type I in $2 \times$ PBS pH8.0) to give $5 \times 10^{5} \mathrm{cells} / \mathrm{ml}$ and $3 \mathrm{mg} / \mathrm{ml}$ of collagen gel solution. One hundred $\mu \mathrm{l}$ of RASMC-collagen gel solution was added per well to 24-well plates. Where indicated, various inhibitors were added. The plate was incubated at $37^{\circ} \mathrm{C}$ to allow for gel polymerization. After $1 \mathrm{~h}$, the gels were floated with serum-free DMEM and Angll was added to initiate contraction while images were captured using a digital chargecoupled device camera. Collagen gel contraction was measured as a decrease in gel area using Scion Image software (compliments of Scion Corporation, Frederick, MD, http://www.scioncorp.com). Relative gel area was obtained by dividing the area at each time point by the initial area of the gel.

\section{Measurement of cytosolic calcium concentration}

Intracellular calcium concentration was measured using fura-2/AM, a calcium-sensitive fluorescent dye, as described previously (Grynkiewicz et al., 1985). Briefly, a total of $2 \times 10^{6}$ RASMCs were incubated with $3 \mu \mathrm{M}$ fura-2/AM at $37^{\circ} \mathrm{C}$ in fresh serum-free DMEM medium with stirring for $50 \mathrm{~min}$. A total of $2 \times 10^{5}$ cells were aliquoted for each assay into Locke's solution $(154 \mathrm{mM} \mathrm{NaCl}, 5.6 \mathrm{mM} \mathrm{KCl}$, $1.2 \mathrm{mM} \mathrm{MgCl}_{2}, 5 \mathrm{mM}$ HEPES, pH 7.3, $10 \mathrm{mM}$ glucose, 2.2 $\mathrm{mM} \mathrm{CaCl}$, and $0.2 \mathrm{mM}$ EGTA). Fluorescence was measured at emission wavelength of $500 \mathrm{~nm}$ using an excitation wavelength of $340 \mathrm{~nm}$ and $380 \mathrm{~nm}$.

\section{Measurement of aortic ring tension}

The thoracic aorta was rapidly removed and immersed in ice-cold modified Krebs' solution (118 mM of $\mathrm{NaCl}, 4.7 \mathrm{mM}$ of $\mathrm{KCl}, 1.2 \mathrm{mM}$ of $\mathrm{MgSO}_{4} \cdot 7 \mathrm{H}_{2} \mathrm{O}, 1.2 \mathrm{mM}$ of $\mathrm{KH}_{2} \mathrm{PO}_{4}, 25$ $\mathrm{mM}$ of $\mathrm{NaHCO}_{3}, 2.5 \mathrm{mM}$ of $\mathrm{CaCl}_{2} \cdot 2 \mathrm{H}_{2} \mathrm{O}, 5.6 \mathrm{mM}$ of glucose, $\mathrm{pH}$ 7.4). The aorta was dissected to remove fat and connective tissue and sliced into rings $(2-3 \mathrm{~mm}$ in length). The aortic rings were suspended by two L-shaped stainless-steel wires inserted into the lumen followed by immersion in $10 \mathrm{ml}$ organ chambers filled with Krebs' solution. The basal tension of the aortic ring was maintained at $2 \mathrm{~g}$ and aerated continuously with $95 \% \mathrm{O}_{2} / 5 \%$ $\mathrm{CO}_{2}$. Changes in isometric tension were recorded using a force-displacement transducer (Grass FT 0.3, Quincy, MA) connected to a Power Lab system 400 (ML 118, PowerLab, AD Instruments, Medford, MA) and saved in a computer. The aortic rings were allowed to equilibrate for $90 \mathrm{~min}$ while changing the chamber solution every $15 \mathrm{~min}$. After resting tension of each vascular specimen had stabilized, maximum tension of each aortic ring was measured after addition of $60 \mathrm{mM} \mathrm{KCl}$. Constricted aortic rings were relaxed by washing with Krebs' solution for $2 \mathrm{~h}$. Various inhibitors were added $20 \mathrm{~min}$ prior to Angll stimulation. 
Angll-induced contraction was expressed as percent of 60 $\mathrm{mM} \mathrm{KCl}$-induced contraction.

\section{Western blot analysis}

VSMCs were lysed in lysis buffer containing $20 \mathrm{mM}$ Tris- $\mathrm{HCl}, \mathrm{pH}$ 7.3, $1 \mathrm{mM}$ EGTA/EDTA, 1\% Triton X-100, 1 $\mathrm{mM} \mathrm{Na} \mathrm{VO}_{4}, 10 \mu \mathrm{g} / \mathrm{ml}$ leupeptin and $10 \mu \mathrm{g} / \mathrm{ml}$ aprotinin. After centrifugation at $12,000 \mathrm{rpm}$ for $5 \mathrm{~min}, 30 \mu \mathrm{g} / \mathrm{ml}$ of total protein was loaded onto a $10 \%$ polyacrylamide gel and, after electrophoresis, transferred to nitrocellulose membranes. Membranes were incubated with the indicated primary antibodies and IR Dye-conjugated secondary antibody. Protein bands were visualized by an infrared image analyzer (Li-COR Bioscience).

\section{Statistical analysis}

Results are expressed as the mean \pm S.D. of two independent experiments ( $n=3$ for each experiment). When two groups were compared, an unpaired Student's $t$-test was used to assess differences. $P$-values less than 0.05 were considered significant.

\section{Acknowledgements}

This work was supported for two years by Pusan National Research Grant to S.S.B.

\section{References}

Baker KM, Booz GW, Dostal DE. Cardiac actions of angiotensin II: Role of an intracardiac renin-angiotensin system. Ann Rev Physiol 1992;54:227-41

Dendorfer A, Dominiak P, Tempel K, Raasch W. Peripheral sympatholytic actions of four AT1 antagonists: are they relevant for long-term antihypertensive efficacy? J Hypert 2005;23:1861-7

Geisterfer AA, Peach MJ, Owens GK. Angiotensin II induces hypertrophy, not hyperplasia, of cultured rat aortic smooth muscle cells. Circ Res 1988;62:749-56

Grynkiewicz G, Poenie M, Tsien RY. A new generation of $\mathrm{Ca}^{2+}$ indicators with greatly improved fluorescence properties. J Biol Chem 1985;260:3440-50

Hall KL, Harding JW, Hosick HL. Isolation and characterization of clonal vascular smooth muscle cell lines from spontaneously hypertensive and normotensive rat aortas. In Vitro Cell Dev Biol 1991;27A:791-8

Ishihata A, Tasaki K, Katano Y. Involvement of p44/42 mitogen-activated protein kinases in regulating angiotensin II- and endothelin-1-induced contraction of rat thoracic aorta. Eur J Pharm 2002;445:247-56

Lassegue B, Sorescu D, Szocs K, Yin Q, Akers M, Zhang Y, Grant SL, Lambeth JD, Griendling KK. Novel gp91(phox) homologues in vascular smooth muscle cells : nox1 mediates angiotensin II-induced superoxide formation and redox-sensitive signaling pathways. Circ Res 2001;88:888-94
Le Blanc C, Mironneau C, Barbot C, Henaff M, Bondeva T, Wetzker R, Macrez N. Regulation of vascular L-type $\mathrm{Ca}^{2+}$ channels by phosphatidylinositol 3,4,5-trisphosphate. Circ Res 2004;95:300-7

Linseman DA, Benjamin CW, Jones DA. Convergence of angiotensin II and platelet-derived growth factor receptor signaling cascades in vascular smooth muscle cells. J Biol Chem 1995;270:12563-8

Marrero MB, Schieffer B, Li B, Sun J, Harp JB, Ling BN. Role of Janus kinase/signal transducer and activator of transcription and mitogen-activated protein kinase cascades in angiotensin II- and platelet-derived growth factor-induced vascular smooth muscle cell proliferation. J Biol Chem 1997;272:24684-90

Meloche S, Landry J, Huot J, Houle F, Marceau F, Giasson E. p38 MAP kinase pathway regulates angiotensin II-induced contraction of rat vascular smooth muscle. Am J Physiol 2000;279:H741-51

Nishida M, Tanabe S, Maruyama Y, Mangmool S, Urayama $\mathrm{K}$, Nagamatsu $\mathrm{Y}$, Takagahara S, Turner JH, Kozasa T, Kobayashi H, Sato Y, Kawanishi T, Inoue R, Nagao T, Kurose, $H$. G $\alpha_{12 / 13-}$ and reactive oxygen species-dependent activation of c-Jun $\mathrm{NH} 2$-terminal kinase and p38 mitogen-activated protein kinase by angiotensin receptor stimulation in rat neonatal cardiomyocytes. J Biol Chem 2005;280:18434-41

Rhee SG. Regulation of phosphoinositide-specific phospholipase C. Ann Rev Biochem 2001;70:281-312

Smith JB, Smith L, Brown ER, Barnes D, Sabir MA, Davis JS, Farese RV. Angiotensin II rapidly increases phosphatidate-phosphoinositide synthesis and phosphoinositide hydrolysis and mobilizes intracellular calcium in cultured arterial muscle cells. Proc Natl Acad Sci USA 1984;81: 7812-6

Sugden $\mathrm{PH}$, Clerk A. Regulation of the ERK subgroup of MAP kinase cascades through $\mathrm{G}$ protein-coupled receptors. Cell Signal 1997;9:337-51

Taniyama Y, Weber DS, Rocic P, Hilenski L, Akers ML, Park J, Hemmings BA, Alexander RW, Griendling KK. Pyk2- and Src-dependent tyrosine phosphorylation of PDK1 regulates focal adhesions. Mol Cell Biol 2003;23:8019-29

Taniyama Y, Ushio-Fukai M, Hitomi H, Rocic P, Kingsley MJ, Pfahnl C, Weber DS, Alexander RW, Griendling KK. Role of p38 MAPK and MAPKAPK-2 in angiotensin II-induced Akt activation in vascular smooth muscle cells. Am J Physiol Cell Physiol 2004;287:C494-9

Uehata M, Ishizaki T, Satoh H, Ono T, Kawahara T, Morishita T, Tamakawa H, Yamagami K, Inui J, Maekawa M, Narumiya $\mathrm{S}$. Calcium sensitization of smooth muscle mediated by a Rho-associated protein kinase in hypertension. Nature 1997;389:990-4

Ushio-Fukai M, Griendling KK, Akers M, Lyons PR, Alexander RW. Temporal dispersion of activation of phospholipase C- $\beta 1$ and $-\gamma$ isoforms by angiotensin II in vascular smooth muscle cells. Role of $\alpha_{\mathrm{q} / 11}, \alpha_{12}$, and $\beta \gamma \mathrm{G}$ protein subunits. J Biol Chem 1998;273:19772-7

Ushio-Fukai M, Alexander RW, Akers M, Lyons PR, Lassegue B, Griendling KK. Angiotensin II receptor coupling 
to phospholipase $D$ is mediated by the betagamma subunits of heterotrimeric $\mathrm{G}$ proteins in vascular smooth muscle cells. Mol Pharm 1999a;55:142-9

Ushio-Fukai M, Alexander RW, Akers M, Yin Q, Fujio Y, Walsh $\mathrm{K}$, Griendling KK. Reactive oxygen species mediate the activation of Akt/protein kinase B by angiotensin II in vascular smooth muscle cells. J Biol Chem 1999b;274:22699-704

Viard P, Exner T, Maier U, Mironneau J, Nurnberg B, Macrez N. G $\beta \gamma$ dimers stimulate vascular L-type $\mathrm{Ca}^{2+}$ channels via phosphoinositide 3-kinase. FASEB J 1999;13:685-94

Watts SW, Florian JA, Monroe KM. Dissociation of angiotensin II-stimulated activation of mitogen-activated protein kinase kinase from vascular contraction. J Pharm Exp
Therap 1998;286:1431-8

Yamada $\mathrm{H}$, Akishita M, Ito M, Tamura K, Daviet L, Lehtonen JY, Dzau VJ, Horiuchi M. AT 2 receptor and vascular smooth muscle cell differentiation in vascular development. Hypert 1999;33:1414-9

Yan C, Kim D, Aizawa T, Berk BC. Functional interplay between angiotensin II and nitric oxide: cyclic GMP as a key mediator. Arterioscle Throm Vasc Biol 2003;23:26-36

Yu J, Tokinaga Y, Ogawa K, Iwahashi S, Hatano Y. Sevoflurane inhibits angiotensin II-induced, protein kinase $\mathrm{C}$-mediated but not $\mathrm{Ca}^{2+}$-elicited contraction of rat aortic smooth muscle. Anesthesiology 2004;100:879-84 